\title{
INVESTIGATIVE JOURNALISM AS A NEW FORM OF JOURNALISM IN THE INFORMATION SOCIETY
}

The issue of so-called investigative journalism, journalistic investigation, certainly deserves serious scientific discussion in every respect. It seems strange that so little interest has been given to this matter in scientific journals as well as in more popular publications. This is made all the more remarkable by the fact that the Journalists' Code of Ethics of the Association of Polish Journalists, ${ }^{1}$ has been in force since 2001, in which it was expressis verbis stated, that in collecting material, journalists must not use any illegal methods and ethically reprehensible behaviour; the exception is the investigative journalist, tracking in the name of public good with the knowledge and consent of his superiors - crime, corruption and abuse of power (art. II pkt 5). Furthermore, in section 6 of that article, it was also stated that journalist should not violate the sphere of privacy and intimacy, an exception may be - in justified circumstances - activities in pursuit of investigations against public figures. The principles of journalistic ethics at TVP SA, also relates to the issue of investigative journalism, treating it as an unique kind of activity - due no doubt, to the activities of investigative journalist being in the greater public interest. According to the principles of journalistic ethics, collecting materials for the program, recording information, speeches, interviews and the like, should be conducted in a manner that is fair and consistent with both the principles of morality and the law in force. It is unacceptable to use methods that are morally reprehensible, methods such as misleading the interlocutor, impersonating other people, hiding the real nature of the conversation being recorded. And of course - the journalist must never behave in a threatening or intimidating manner. The only exception to this principle, is the use of a hidden camera or hidden microphone - in the greater public interest - to covertly obtain important information that would otherwise be impossible to come by.

Investigative Journalism (Investigative Reporting, journalism d'enquete), according to TVP SA's principles of journalistic ethics, is to denounce the abuse of power, fraud, corruption, crime - by obtaining evidence of guilt which in any 
event can not serve the interests of any particular individuals or groups. It is also necessary to pay attention to the fact that a hidden camera or microphone may violate the right to privacy, therefore, in each instance where this practice is to be adopted, it must first be approved by a supervisor and even with that sanction, it can still only proceed with the approval of the person being filmed or recorded. Recording telephone conversations without any intention of issuing the required notice to the person on the other end of the line, is unacceptable - unless of course, it serves the public good. In the principles of TVP SA, it has also been concluded that investigative journalism is the domain of journalists with extensive experience and a reputation for professionalism and ethical propriety. ${ }^{2}$ These ethical statements must surely serve to promote debate, not only on labour standards, but on the rules of conduct, and especially so where investigative journalism is concerned. Such debate is also important in another respect - journalism is a profession of public trust. ${ }^{3}$

Investigative journalism is a form of journalism which in Poland is not rich in tradition, because its development requires specific sociopolitical conditions in which to exist. In a word, it is primarily a system of 'power'. which can only be effective in countries receptive to public opinion. Such conditions occurred in Poland after 1989, when the political system was changed to that of a parliamentary democracy and the country returned to a market economy. In 1994, the Polish essayists had come into being and they introduced the concept of "deceptive journalism", journalism that is provocative. ${ }^{4}$ The most famous example of provocative journalism of that time, was carried out by E. Wanat and M. Gorzeliński, who "stole" a car and drove it around Poznan, under the noses of police patrols. That provocation exposed the low efficiency of the Polish police and deficiencies in the management and coordination of its activities. There were other provocations which followed ${ }^{5}$. At this point it should be noted that according to M. Palczewski, ${ }^{6}$ the techniques used by investigative journalists to obtain information, such as leakages or provocations, has nothing to do with investigative journalism. This view can be accepted but with the proviso, that the essence of investigative journalism is the determination of facts ${ }^{7}$

2 http://www.tvp.pl/o-tvp/komisja-etyki/podstrony/rozwiniecie-zasad/105763

3 See: Opinia społeczna na temat zawodów zaufania publicznego komunikat z badań, Warszawa, April 2004, http://www.cbos.pl/SPISKOM.POL/2004/K_073_04.PDF

4 Małgorzata Wyszyńska in "Press" nr 1, 2005 has documented the phenomenon in Poland.

5 In 1995, journalists of „Super Express” without any difficulty obtained a large quantity of dynamite. In 2003, journalists of Newsweek and TVN in exchange for a bribe (700 PLN) received a favorable decision in the department of architecture of Krakow's city council. In 2004, TVN journalists in exchange for a bribe, received from a psychiatrist in Kielce, a fictional mental health certificate for submission to the police. In 2005, journalists of TVN and journalists of "Newsweek" bought false documents at the market and used them freely to buy expensive equipment on credit, rent cars and an apartment, and tried to open a bank account. In 2005, the journalists of "Ekspres Reporterów" and TVP2 reveal the illegal activities of a gynecologist in Kożuchów, who suggested paid for an abortion to a woman who was not pregnant. A TVN journalist exposed the trade in fake paintings in the famous Auction House.

6 Dr, Wyższa Szkoła Humanistyczno-Ekonomiczna w Łodzi.

7 On the original findings of the journalist and independence on the findings made by other authorities designated for that: the police, prosecutor or special services as the essence of investigative journalism also notes A Marsza- 
using a variety of techniques for collecting information (informers, leaks, journalistic provocation, and the like). Which method is used depends on the circumstances, it is not dependent on the use of one technique over another. As B. Page, rightly puts it, investigative journalism is all about investigation. It is not about asking important people what happened. The idea is to independently arrive at this ${ }^{8}$. Similarly, investigative journalism can not be reduced solely to news gathering, the collection of information, because investigative journalism is not just about "finding what is hidden" but also for disclosing it and publishing the facts ${ }^{10}$. S. Tendler ("The Times") expresses this very clearly, claiming that: "...the investigative journalist can not be the depository of secrets, since they pay him for it". ${ }^{11}$

As indicated above, investigative journalism, which leads to the disclosure of acts of wrongdoing in public life and brings them to the attention of the general public, can not develop under the rule of a dictatorship, where the people and their participation in public life are subjugated under the instrument of totalitarian power. The communist government in Poland did not allow the truth to be revealed - the truth about the mechanisms of totalitarian governance, its abuses, its nepotism, its poverty, its unemployment and its common crimes. The rights and freedoms of the citizen were violated and public awareness was subject to indoctrination and propaganda. Even in the incapacitated and communist government controlled media, strict censorship was in force. However, in a democratic system, journalism - especially investigative journalism - is primarily a form of independent power and social control over the authorities. By raising awareness and shaping public opinion, investigative journalism undoubtedly affects, albeit in an indirect way, politics and governance. ${ }^{12}$ However, investigative journalism also has a direct influence on the formation and development of civil society and both strengthens and smooth's the functioning of democracy. ${ }^{13}$ It should be emphasized that investigative journalists cannot replace the constitutional state bodies in carrying out the tasks to which they have been appointed. According to art. 10 of the European Convention on Human Rights, ${ }^{14}$ a free, independent and pluralistic media is crucial in a democratic society. It should also be noted, that this type of journalism is a very difficult labour, one that is time-consuming, costly and potentially dangerous. For its effectiveness, it

łek in the discussion: Jak problem zagrożenia korupcją w Polsce byłpostrzegany przez międzynarodowe organizacje w 1999 r. i obecnie, http:// WWW.batory.org. pl/korupcja/sesja1.htm D. Spark, Dziennikarstwo śledcze. Studium techniki, Kraków 2007, p. 2.

W.M. Rivers, C. Mathews, Etyka środków przekazu, Warszawa 1995, p. 119

Zob. M. Zaremba, Śledztwo dziennikarskie. Teoria i praktyka w Polsce, Europie i Stanach Zjednoczonych, Łódź 2006, p. 89.

D. Spark, op. cit., p. 18.

Zob. J. Jastrzębski, Etyka dziennikarstwa śledczego., (w:) Śledztwo dziennikarskie. Teoria i praktyka..., op. cit., p. 43 and the following.

Zob. M. Bierzyńska-Sudoł, Rola dziennikarstwa śledczego w budowaniu demokracji i społeczeństwa obywatelskiego, (w:) Teoria i praktyka..., p. 82 in.

The Convention for the Protection of Human Rights and Fundamental Freedoms. 
must necessarily be equipped, in every respect, with the status of independence. These difficulties were pointed out by the late Pope John Paul II, ${ }^{15}$ who believed that journalists constantly feel the pressures of power, in all its various forms ideologically and economically. The Pope, pointed out that journalists often have to work - perhaps like no other beings - within a very limited time span, sometimes being required to write about things that deviate from their rules, or even conflict with them. The Pope, observed that often the professional activities of journalists, forced them to remain away from family and home, moving from country to country with frequent changes of residence. Continuous, arduous, journalistic investigation, regardless of the level of frustration, requires a proper moral attitude from the investigative journalist. This is undoubtedly a mission. Investigative journalism was once known in the UK as journalism, bringing relief to victims and the demolition peace sated and satisfied. This is a fight in the name of readers. ${ }^{16}$ There is no doubt that journalism is an act of communication between the journalist and society. ${ }^{17}$

Although Polish investigative journalism can not boast a long pedigree, it was nevertheless not spared in the crisis which occurred as a consequence of events that created disequilibrium in the mass media market. ${ }^{18}$ In my opinion, one of the most important factors, was the "chaotic" situation created by the liquidation of the RSW Group (group "RSW Prasa - Ksiazka - RUCH"), a division of the media, which resulted in the "oligarchic shape" of the media in Poland, and a poor ratio between public and commercial media. It should be noted that there is a direct correlation of state authority, the model of mass media access to the information unit and its quality. Other factors affecting the function and model of mass media are: the statutory regulations in the field of media, the share of foreign capital in the media and the applicable ethical standards involved. In addition, one needs to point to the computerization process of socioeconomic life, which brings Poland to the era of the information society, a society shaped primarily by the introduction and development of electronic media. Information civilization is a new quality based on freely available information. Information is also a basic commodity that is subservient to market forces and which directly conditions qualitative changes in all areas of social life. In this sense, it adds a totally different dimension to the right to information - freedom of information. What remains constant, however, is the fact that this freedom is not absolute, since, in the broader sense, it is still subject to constraints generated by the need to protect freedom of communication, privacy and security. In this latter respect in particular, unlimited access to electronic communication and universal access to electronic media, at any time and in any place, also serve to generate a

A speech delivered to journalists in Rome location of Catholic Press Association in Italy, Rome, 17th of January 1988.

D. Spark, op. cit., p. 6

Pope John Paul II.

Newspapers lose out in relation to the Internet 
new and severe phenomena - cyber-crime - and any individual participating in the information society, is not immune to its dangers. On the other hand, unlimited access to electronic communication and the widespread availability of electronic media, has determined a new and distinctive cultural phenomena - a new human activity. Of course, alongside electronic media, printed media continues to exist in its traditional form, with the printed media being complemented by on-line products.

Referring to the first topic of discussion, investigative journalism, at this point it is now worth mentioning the other forms of journalism that have developed. If it is assumed that the essence of journalism is public communication by means of mass communication, electronic media such as the Internet, now plays a dominant role. Thus, depending on the adopted criterion, journalism can mainly be divided into: public (non-commercial) and commercial; professional (performed by professional journalists) and non-professional; press, radio, television and internet (the so-called electronic media); news, current affairs, local, national and international; professional, political, economic, sporting, cultural, etc. This division shows an existing variety of journalistic forms and those which, with the development of the information society, are evolving into new solutions every day. Hence, more than seventy-percent of Internet users claim that public journalism will be crucial in the future. We should understand that under the concept of public journalism, what we are looking at is journalism practiced by ordinary members of the public in the public interest, using as a medium of mass communication - the Internet. Clearly, therefore, the rise and development of public journalism is directly linked to the rise of the Internet, which allows anyone to create interactive information for mass publication. The first public journalism site to be created in Poland, is considered to be the Polish language version of Wikipedia, which was created on 19 February $2005 .{ }^{19}$ Other journalistic sites to which members of the public contribute, have since been opened by the publishers of professional media. The largest such sites are: Wiadomosci24.pl, Interia360.pl, iThink.pl, eioba.pl, salon24.pl. One can also point to other developing journalistic activities, using the different tools and options available, such as: blogs ${ }^{20}$, general or specialized social networking sites, horizontal portals ${ }^{21}$, vertical portals (thematic) ${ }^{22}$,

http://pl.wikipedia.org/wiki/Wikinews

Blog (or web log) - Form of website containing entries created by the blog owner (blogger). All blogs are regarded as a communication medium called the blogosphere. Blogs are mostly the personal views and comments of the blogger. Blogs can be used as a vertical portals.

Internet portal - an online news service. It contains information available to an unlimited audience, such as current news, weather, web directory, chat, forums and mechanisms to locate information peer-to-peer or via external Internet based resources (search engines). Polish web portals include: Onet.pl, Wirtualna Polska.pl,, Interia pl, Gazeta.pl, 02.pl, TVN24.pl, TVP.info.pl, RMF24.pl, Fakt.pl, Polonia.net, Polska.pl, Poland.com, RadioZET.pl Web site, a vertical portal - a specialized portal, containing information from one field, the theme, such as for film, music, computer programs, automotive. It should be noted that the information content of a particular news portal is more specialized compared to the portals. 
public journalism sites, internet TV stations ${ }^{23}$, Internet radio stations ${ }^{24}$. Therefore it seems reasonable to say that public journalism (in the broad sense) will - in any form and using various forms of electronic media primarily centred on the Internet - will continue to develop dynamically. This does not mean that traditional media will disappear, though doubtless, it will need to develop new strategies to main its presence, particularly on-line. It seems that the evolution of online media, should also be used for the development of professional journalism and traditional media. However, judging public journalism on its merits, it should be emphasized that it provides a better understanding of events in a localised context, is quick and easy to apply (in terms of publishing information and material) and affords independence (in relation to a specific line of programming, and the assessment and approval of an editorial board). However, its main disadvantages are: lack of journalism workshop, objectivity, a peculiar one-sidedness and single-thematic information. Furthermore, it should also be noted that public journalism has a tendency to generate secondhand information in the form of comments or the reorganization of reports emanating from professional journalists.

Thus it seems reasonable to proceed to the question of what lays in store for the future of journalism in Poland? What will be the impact on the labour-intensive, time consuming, costly, dangerous, independent investigative journalism, if a crisis arises in the mass media market in Poland? Will, in the near future, any member of the public armed with a computer, a camera phone, or camera, be able to compete with the investigative journalist? The answer to this question is not so simple, given the specificity of the investigative journalists work and the fact that, in accordance with Art. 72 point 5 of the Act of 26 January 1984 - Press Law, a journalist is a person engaged in the preparation, compilation and editing of press materials under the authority of an editor. Without delving deeper into this definition, it is quite clear that, above all, reliable and original (primary) information, can only, and likely always will, be created by professional journalists. In this respect, it is also worth noting that the quality of the information, as well as the standards of its presentation, are a prerequisite. Ch. Fasel (Stern), aptly notes that: the journalist is not an artist, but is a craftsman. Referring to the specifics of investigative journalism, it should be noted that the journalist must posses strength, tenacity, determination and patience. Leading an investigation also needs support. Top stories require painstaking work and time. They are extremely expensive, they are often dangerous, and they also require a thorough knowledge of investigative procedures. According to T. Bower ${ }^{25}$ "...fair journalism is expensive, frustrating and a lonely grind. Often it turns out to be

Internet TV - TV which uses the transmission medium of the Internet and which will make its television programs on the Internet. For the reception of such programs appropriate software is needed

24 Internet radio - radio which broadcasts via the Internet and it is mostly produced by amateurs. Traditional radio stations also use the Internet as an additional broadcasting channel.

T. Bower following D. Spark, op. cit., p. 15 
futile and inefficient. Even the rare success only brings to the investigative reporter unpleasant epithets: he is described as 'obsessive' and 'dangerous.' The final product is often complicated, difficult to read, not very interesting and unconvincing." Consideration of this effort is primarily the satisfaction of knowing that something has been done, that was almost impossible to achieve, in order to help someone that has suffered an injustice. This is why investigative journalism is sometimes described as, involved journalism.

In considering the issue of investigative journalism it is impossible not to refer to the workshop and the working methods of investigative journalist. From the outset the definition of investigative journalism, put forward quite a surprising observation that a reporter investigating in Poland, is allowed to do just about anything. But this is not a fully justifiable claim, because the journalist is not relieved of liability for his actions, although it is worth mentioning that the Polish justice system treats media's cases gently. What needs to be strongly emphasized, is that any statutory provision must not be in conflict with applicable law. Investigative journalist must be aware of this when citing "ethics" in defence of a breach of law: it will not protect him from either civil liability or criminal liability. Characteristic, even constitutive of this kind of journalism, is a paradox: a noble goal requires the methods and means of controversial ethics. However, in my opinion, belief that "the end justifies the means" is not valid, because the most important virtue of investigative journalism should be the virtue of credibility. According to the standards of the legendary British investigation team, "The Sunday Times", the model of journalistic integrity - investigative reporters are required to be intransigent in their search for evidence, determining facts and reviewing the sources of information, especially in drawing conclusions, and must be ready to reject theories that are tempting but deceptive". Even the slightest wrong detail can undermine the entire investigation. Public good is the respect for existing law by all citizens including journalists - especially investigative reporters, and no one can put themselves above the law. Moreover, it is the lot of the investigative journalist to protect peoples interests, whether that be the protection of a persons rights or their dignity, the protection of minors against immorality, the protection of 'whistleblowers' acting in good faith, or the protection of others, who turn to and place their trust in the reporter.

In conclusion, I cite the opinion of John Paul II on journalistic ethos, which he expressed on 4 June 2000, at an event organized for journalists by the Vatican in celebration of World Communications Day. According to John Paul II ".... since journalism has such a vast and direct influence on public opinion it can not be controlled solely by economic factors, the pursuit of profit and partisan interests. It should be seen as a task, in some sense "sacred", performed with the knowledge that the powerful media reporters are assigned for the benefit of vulnerable groups - from children to the poor, the sick to the people marginalized and discriminated 
against. It can not be written or broadcast in programs, guided by the desire to obtain the largest possible audience, abandoning the very formative influence. Also it can not refer indiscriminately to the right to information, not taking into account other human rights. No freedom, including freedom of expression is absolute: in fact, facing the border in the form of the obligation to respect the dignity and legitimate freedom of others. It can not be written, produced and broadcast in programs, if it prejudices the truth: not only the truth of the facts of which it informs the public, but also the truth about man, human dignity in all its dimensions." 


\section{INVESTIGATIVE JOURNALISM AS A NEW FORM OF JOURNALISM IN THE INFORMATION SOCIETY}

This article provides an introduction to discussion on the issue of investigative journalism as a new form of journalism in the information society. The issue of socalled investigative journalism undoubtedly deserves serious scientific discussion in every respect, especially if one takes into account the fact that investigative journalism is an unique kind of journalistic activity due to it being in the greater public interest, albeit in the absence of the power and authority inherent in the disclosure and explanation of criminal offenses. Investigative journalism is a type of journalism, which in Poland is not rich in tradition because its development depends on sociopolitical conditions.

Since 2001, in Poland a Code of Ethics of Journalism Association of Polish Journalists is in force, in which it was expressly stated that: in collecting material journalists must not use any illegal methods and ethically reprehensible behavior, the exception is investigative journalists, such as tracking in the name of public good with the knowledge and consent of their superiors - crime, corruption or abuse of power (Article II, paragraph 5). Furthermore, in section 6 of the same article, it was also stated that journalist should not violate the sphere of privacy and intimacy, an exception may be - in justified circumstances - activities in pursuit of investigations against public figures.

The quoted definition of investigative journalism show quite surprising assertions that the investigative reporter in Poland, is allowed to do just about anything. But this claim is not fully justifiable, because the journalist is not relieved of responsibility for his actions, although it is worth mentioning that the Polish justice system treats media cases gently. Considering the issue of investigative journalism, it is impossible not to refer to the workshop and working methods of investigative journalist.

Key words: journalism, Internet, investigation, ethics, information society 
Niniejszy artykuł stanowi wstęp do dyskusji dotyczącej problematyki dziennikarstwa śledczego jako nowej formy dziennikarstwa w społeczeństwie informacyjnym. Problematykatzw. śledztwa dziennikarskiego niewątpliwie zasługuje na poważną dyskusję naukową pod każdym względem, szczególnie zaś, jeśli weźmie się pod uwagę okoliczność, iż dziennikarstwo to jest wyjątkowym rodzajem działalności dziennikarskiej z uwagi na działanie dziennikarza śledczego w imię wyższego interesu publicznego przy jednoczesnym braku uprawnień i kompetencji właściwych dla organów ścigania w zakresie ujawniania i wyjaśniania popełnionych przestępstw. Dziennikarstwo śledcze jest rodzajem dziennikarstwa, który w Polsce nie ma bogatej tradycji, gdyż do swojego rozwoju potrzebuje charakterystycznych warunków społeczno - politycznych. Od 2001 r. w Polsce obowiązuje Kodeks Etyki Dziennikarskiej Stowarzyszenia Dziennikarzy Polskich, w którym expressis verbis zostało stwierdzone, iż w zbieraniu materiałów nie wolno posługiwać się metodami sprzecznymi z prawem i nagannymi etycznie; wyjątkiem jest dziennikarstwo śledcze, tj. tropienie $w$ imię dobra publicznego - za wiedzą i zgodą przełożonych - zbrodni, korupcji czy nadużycia władzy (art. II pkt 5). Ponadto w punkcie 6 tegoż artykułu ustalono również, iż nie wolno naruszać prywatności i sfery intymnej; wyjątek mogą stanowić - w uzasadnionych okolicznościach - działania w zakresie dziennikarstwa śledczego, także wobec osób publicznych. Z przytoczonej definicji dziennikarstwa śledczego wynika dość zaskakująca konstatacja, że reporterowi śledczemu w Polsce wolno właściwie wszystko. Nie jest to jednak twierdzenie w pełni uzasadnione, gdyż dziennikarz nie jest zwolniony z odpowiedzialności za swoje czyny, chociaż zauważyć wypada, że polski wymiar sprawiedliwości łagodnie traktuje tzw. kazusy medialne. Rozważając problematykę dziennikarstwa śledczego nie sposób nie odnieść się również do kwestii warsztatu i metod pracy dziennikarza śledczego. 